\section{High Electrical Conductivity and Radiation-based Water Management Improve Fruit Quality of Greenhouse Tomatoes Grown in Rockwool}

\author{
Simon Chrétien and André Gosselin \\ Horticultural Research Center, Laval University, Sainte-Foy, QC, Canada \\ G1K $7 P 4$ \\ Martine Dorais ${ }^{1}$ \\ Agriculture and Agri-Food Canada, Horticultural Research Center, Laval \\ University, Sainte-Foy, QC, Canada G1K $7 P 4$
}

Additional index words. electrical conductivity, fertigation, fruit cracking, growth, Lycopersicon esculentum, mineral analysis, $\mathrm{NaCl}$, water potential, yield

\begin{abstract}
In order to improve fruit quality under the Northern climatic growing conditions prevailing in Quebec, Canada (lat. $47^{\circ} \mathrm{N}$, long. $71^{\circ} \mathrm{W}$ ), a greenhouse tomato (Lycopersicon esculentum Mill. cv. Blitz) spring production experiment was conducted using several irrigation regime and electrical conductivity (EC) levels. The irrigation regime treatments were a function of the global solar radiation, with three thresholds applied to each EC treatment. The irrigation thresholds $\left(\mathrm{KJ} \cdot \mathrm{m}^{-2}\right)$ were 1) 468, 2) 540, and 3) 612. Two EC treatments were used: 1) control EC $\left(2.0\right.$ to $\left.3.5 \mathrm{mS} \cdot \mathrm{cm}^{-1}\right)$ and 2$) 30 \%$ higher EC than the control $\left(2.6\right.$ to $\left.4.6 \mathrm{mS} \cdot \mathrm{cm}^{-1}\right)$, which was raised by adding $\mathrm{NaCl}$ to 12 $\mathrm{mmol} \cdot \mathrm{L}^{-1}$. Plant water potential in summer and in the fall and plant growth after 6 months were not affected by irrigation or EC treatments. Raising the EC increased the Na content of reproductive and vegetative parts and decreased the $N$ concentration of the vegetative parts. The highest $\mathrm{EC}$ improved fruit quality by reducing the incidence of fruit cracking. Although marketable yields were not affected by $\mathrm{EC}(P=0.09)$ or irrigation regime $(P=0.08)$ treatments, higher EC during March to September increased $(P \leq 0.01)$ the proportion of Class 2 fruit by reducing fruit size.
\end{abstract}

Many environmental and cultural factors can improve the quality of greenhouse tomatoes. Optimal control of greenhouse climate, combined with appropriate fertigation management, may help to maximize tomato fruit quality. Many studies have been conducted on fertigation management of greenhouse tomatoes (de Kreij, 1995; Pearce et al., 1993; Tüzel et al., 1994; Voogt and Sonneveld, 1997). However, more information is needed on these new fertigation techniques for the climatic conditions in northeastern America.

Water management influences the rhizosphere environment (e.g., media water potential and salt accumulation), which in turn affects plant growth and photosynthesis (Atherton and Rudich, 1986). Yield, the bal-

Received for publication 12 May 1999. Accepted for publication 20 Sept. 1999. This research was supported by Agriculture-Québec and Les Productions Horticoles Demers. We thank Pierre-André Dubé for his valuable advice and Réjean Demers, DominiqueAndré Demers, Fabien Labbé, Rachel Daigle, Claudette Roy, Nicole Deblois, Johanne Caron, and Sébastien Bolduc for their technical assistance. The cost of publishing this paper was defrayed in part by the payment of page charges. Under postal regulations, this paper therefore must be hereby marked advertisement solely to indicate this fact.

${ }^{1}$ To whom reprint requests should be addressed. E-mail address: Martine.Dorais@plg.ulaval.ca ance between reproductive and vegetative parts, and tomato fruit size may also be controlled by water supply. Water deficit and changes in light intensity may reduce growth rate and impair metabolic processes. Tüzel et al. (1994) demonstrated that more frequent irrigation improved the growth rate and reduced the dry matter content of fruits, whereas water stress that occurred in the middle of the diurnal period reduced fruit expansion (Pearce et al., 1993). The daily rate of water uptake by a fruiting tomato plant is $1.4 \mathrm{~L}$ (Adams, 1989). In practice, Ho and Adams (1995) have reported that the volume and frequency of irrigation is $120-130 \mathrm{~mL}$ per $\mathrm{MJ} \cdot \mathrm{m}^{-2}$ of solar radiation received per plant for a fruiting tomato crop. Therefore, the water and nutrient supply are matched with the carbon assimilation or growth rate of the crop, resulting in balanced growth (Ho and Adams, 1995).

Conductivity adjustment is also useful for growers to modify the water availability to the crop and hence the vegetative and reproductive vigor of the plants, which in turn influences fruit quality (Holder and Christensen, 1989; Massey et al., 1984; Rudich et al., 1977). Salinity directly influences plant water relations because osmotic stress reduces water uptake (Ho and Adams, 1995; Voogt and Sonneveld, 1997). When light intensity is low, tomato flower and fruit development can be improved by raising the electrical conductivity (EC) (Ho and Adams, 1995). Moreover, increasing the $\mathrm{EC}$ of the nutrient solution could be a very powerful tool for controlling fruit cracking and deformity (Sonneveld and Van Der Burg, 1991). Fruits grown under these conditions tend to have a thicker and more resistant cuticle. They also have a low turgor pressure because of reduced water absorption by roots under a low osmotic potential ( $\Psi$ s) of the nutrient solution and a more resistant xylem transport system in the fruit (Ho and Adams, 1995).

An increase in the EC of the nutrient solution can easily be achieved by adding $\mathrm{NaCl}$, which is less expensive than major nutrients such as $\mathrm{N}, \mathrm{P}, \mathrm{K}, \mathrm{Ca}$, and $\mathrm{Mg}$. Furthermore, increasing $\mathrm{EC}$ with $\mathrm{NaCl}$ has no effect on yield, when the rhizosphere concentration is maintained within plant limit threshold (Adams, 1987; Sonneveld and Van Der Burg, 1991). Sonneveld and Van Der Burg (1991) reported that adjusting the $\mathrm{EC}$ to $1.5 \mathrm{mS} \cdot \mathrm{cm}^{-1}$ with major nutrients allowed maximum yield, and that all subsequent increases in EC could be achieved by adding $\mathrm{NaCl}$ without causing physiological disorders, as long as the total $\mathrm{NaCl}$ concentration in the rhizosphere did not exceed $12 \mathrm{mmol} \cdot \mathrm{L}^{-1}$. Although Adams (1987) established this threshold at $37 \mathrm{mmol} \mathrm{NaCl}$, we did not observe any negative effects at 25 $\mathrm{mmol} \cdot \mathrm{L}^{-1}$ (Dorais et al., unpublished data). Differences in climatic and cultural conditions probably explain these differences in the threshold limit.

The purpose of this investigation was to improve fruit quality of greenhouse tomatoes grown under spring climatic conditions prevailing in northeastern North America, specifically the Quebec area. To achieve this objective, two salinity and three irrigation regime treatments were compared, and their effects on plant water potential, mineral tissue content, growth, yield, and fruit quality were measured.

\section{Materials and Methods}

The experiment was conducted in Venlo glasshouses located at the Horticultural Research Center at Laval Univ. (lat. $47^{\circ} \mathrm{N}$, long. $71^{\circ} \mathrm{W}$ ), Quebec, Canada, from Dec. 1996 to Sept. 1997. 'Blitz' tomato plants were cultivated in rockwool slabs (Talent, series Grodania A/S, Hedehusene, Denmark) and fertigated with a standard nutrient solution (11-15 $\mathrm{mm} \mathrm{NO}_{3}^{-}, 0.4 \mathrm{~mm} \mathrm{NH}_{4}^{+}, 7.5-11 \mathrm{~mm} \mathrm{~K}$, 7-12 mм Ca, 3-5 mm Mg, 1.5-2.0 $\mathrm{mm} \mathrm{H}_{2} \mathrm{PO}_{4}$, 2-3.2 $\mathrm{mm} \mathrm{SO}_{4}, 1.5 \mathrm{mg} \cdot \mathrm{L}^{-1} \mathrm{Fe}, 0.75 \mathrm{mg} \cdot \mathrm{L}^{-1} \mathrm{Mn}$, $0.10 \mathrm{mg} \cdot \mathrm{L}^{-1} \mathrm{Cu}, 0.33 \mathrm{mg} \cdot \mathrm{L}^{-1} \mathrm{Zn}, 0.35 \mathrm{mg} \cdot \mathrm{L}^{-1} \mathrm{~B}$, $\left.0.05 \mathrm{mg} \cdot \mathrm{L}^{-1} \mathrm{Mo}\right)$. Plant density was $2.5-2.8$ plants $/ \mathrm{m}^{2}$. Relative humidity $(\mathrm{RH})$ varied between $60 \%$ and $80 \%$ and air temperature between $21^{\circ} \mathrm{C}$ day $/ 17^{\circ} \mathrm{C}$ night $\pm 1^{\circ} \mathrm{C}$. The $\mathrm{pH}$ of the nutrient solution was maintained between 5.5 and 6.0 with phosphoric or nitric acid. Daily samples of nutrient solution were taken from the rockwool slabs so that $\mathrm{EC}$ and $\mathrm{pH}$ levels could be adjusted if necessary. $\mathrm{CO}_{2}$ was 
injected into the air, except during the summer period (June to August), to maintain a concentration of $600 \mathrm{mg} \cdot \mathrm{L}^{-1}$ in the greenhouse. The climate (air temperature, mechanical ventilation, vapor pressure deficit, light, $\mathrm{CO}_{2}$ ) and the irrigation regime treatments were controlled by computer using the Insight software, version 2.2 (Landis \& Gyr Powers, Siemens, Ill.).

Yield and fruit quality were evaluated biweekly during 26 weeks. Class 1 fruits weighed $>90 \mathrm{~g}$ with no physiological disorder, Class 2 fruits $70-90 \mathrm{~g}$ with no physiological disorder, and Class 3 fruits $<70 \mathrm{~g}$, or had physiological disorders such as blossom-end rot (BER), gold specks, uneven ripening, puffiness, radial or circular cracking and russeting, or a deformity. The marketable yield consisted of all classes except for fruits with BER, deformity, or radial and circular cracking. Leaf area and shoot dry weight were measured every 2 months on three samples per experimental unit (E.U.). Relative growth rate (RGR, $\left.\mathrm{g} \cdot \mathrm{g}^{-1} \cdot \mathrm{d}^{-1}\right)$, specific leaf area $\left(\overline{\mathrm{SLA}}, \mathrm{cm}^{2} \cdot \mathrm{g}^{-1}\right)$, average specific leaf area (SLA, $\left.\mathrm{cm}^{2} \cdot \mathrm{g}^{-1}\right)$ calculated for both dates of sampling, and net assimilation rate (NAR, $\mathrm{g} \cdot \mathrm{cm}^{-2} \cdot \mathrm{d}^{-1}$ ) were calculated following Brown (1984) and the harvestindex was calculated as [(fruit fresh weight/ total plant fresh weight above-ground) $\times 100$ ] . Mineral analyses were done on shoot, fruits, and nutrient solutions extracted from the rockwool slabs to determine the concentra- tions of $\mathrm{N}, \mathrm{P}, \mathrm{K}, \mathrm{Ca}, \mathrm{Mg}$, and $\mathrm{Na}$ on three samples per E.U. Prior to extraction, plant tissues were digested as described by Isaac and Johnson (1960). A spectrophotometer (U1100; Hitachi, Tokyo) was used to determine the total $\mathrm{N}$ and $\mathrm{P}$ concentration of the plant tissues using colorimetric methods described by Bremner and Mulvaney (1982) and Chapman and Pratt (1961), respectively. The same spectrophotometer was used to determine the phosphate and nitrate concentrations of the nutrient solutions according to Murphy and Riley (1962) and Norman et al. (1985), respectively. Concentrations of $\mathrm{K}, \mathrm{Ca}, \mathrm{Mg}$, and $\mathrm{Na}$ in the tissue and in the nutrient solutions were determined with an atomic absorption spectrometer (3300; Perkin-Elmer, Ueberlingen, Germany). Plant water status in summer (21 June) and autumn (24 Sept.) was determined using a pressure chamber $(600$; PMS Instruments, Corvallis, Ore.) following the method of $\mathrm{Xu}$ et al. (1997). The water potential of the nutrient solution from the rockwool slabs was measured with an osmometer (5500 Wescor vapor pressure osmometer; Wescor, Logan, Utah). For each analysis we used three samples per replicate for a total of nine measurements per treatment.

The experiment was arranged as a $2 \times 3$ factorial with two EC levels and three irrigation regime in a split-plot design with three replicates (54 plants per E.U.). The two EC treat- ments were: control $\left(2.0\right.$ to $\left.3.5 \mathrm{mS} \cdot \mathrm{cm}^{-1}\right)$, and $30 \%$ higher than the control (2.6 to 4.6 $\mathrm{mS} \cdot \mathrm{cm}^{-1}$ ), which was raised by adding $\mathrm{NaCl}$ $\leq 12 \mathrm{mmol} \cdot \mathrm{L}^{-1}$. The irrigation regime was a function of the global solar radiation with three thresholds applied to each EC treatment. The thresholds were established at $468(\mathrm{~F} 1), 540$ $(\mathrm{F} 2)$, and $612 \mathrm{KJ} \cdot \mathrm{m}^{-2}$ of solar radiation received (F3) using a model described by de Halleux and Gauthier (1998). A drip irrigation system supplied $100 \mathrm{~mL}$ of nutrient solution per plant per irrigation period. Thus, $\mathrm{F} 1$ had the highest and F3 the lowest irrigation frequency and daily irrigation volume (Fig. 1). The irrigation period was adjusted during the growing season to obtain $55 \%$ to $60 \%$ of water content in the rockwool slabs at dawn. Irrigation regime and EC treatments began on 17 Feb. and the first harvest was 20 Mar. 1997. Main effects and interactions were analyzed for significance using the analysis of variance (ANOVA) (GLM) procedure (ver. 6.12; SAS Inst., Cary, N.C.). Means were compared using a prior contrast analysis (Steel and Torrie, 1980).

\section{Results}

From March to September, salinity and irrigation regime treatments had no effect on shoot dry weight $(317 \mathrm{~g})$, leaf area $(10,244$ $\left.\mathrm{cm}^{2}\right)$, fruit dry matter $(5.4 \%)$ or plant growth rate $\left(\mathrm{RGR}\right.$ of $10.9 \times 10^{-3} \mathrm{~g} \cdot \mathrm{g}^{-1} \cdot \mathrm{d}^{-1}$, NAR of 3.6

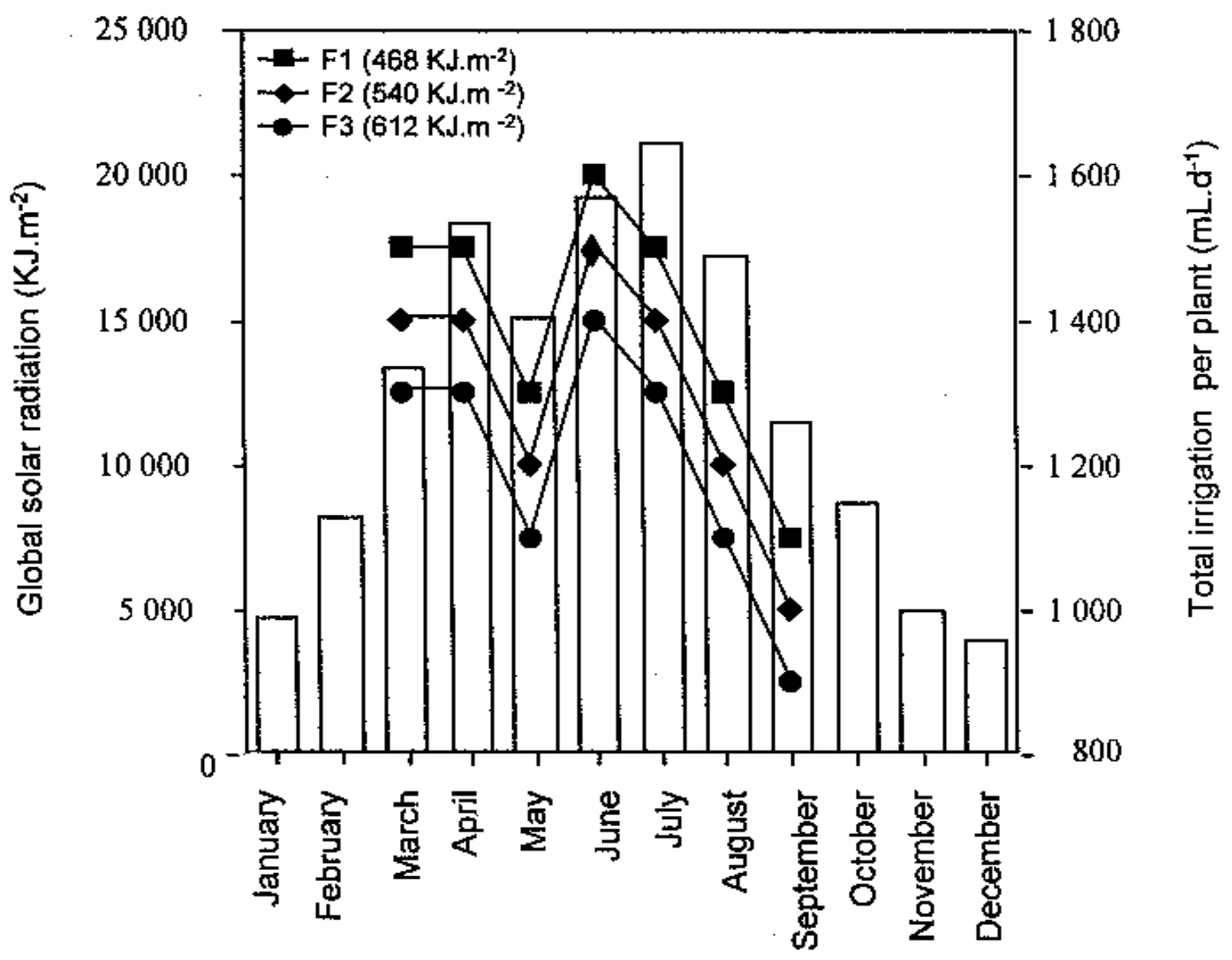

Fig. 1. Mean daily global solar radiation and irrigation. 
$\left.\times 10^{-4} \mathrm{~g} \cdot \mathrm{cm}^{-2} \cdot \mathrm{d}^{-1}\right)$. However, a significant interaction between salinity and irrigation treatments was observed for specific leaf area (SLA) in May $(P=0.03)$ and in July $(P=0.02)$ for $\overline{\mathrm{SLA}}(\longrightarrow)$ (data not shown). From week 15 of harvest until the end of the experiment, total yield in the control EC treatment, receiving the most water $(\mathrm{F} 1)$, was greater than that of the high EC treatment receiving the least water (F3) (Fig. 2). Differences among the other EC and irrigation regime treatments were nonsignificant. After 26 weeks of harvesting (16 Sept.), the weight of Class 1 fruit (Table 1), harvest index and marketable yield (data not shown) were not significantly affected by either EC ( $P=0.81, P=0.89$, and $P=0.09$, respectively) or irrigation $(P=0.60, P=0.82$, and $P=0.08$, respectively) treatments.

Regardless of the irrigation regime, raising $\mathrm{EC}$ with $\mathrm{NaCl}$ increased $(P \leq 0.01)$ the weight of Class 2 fruit by $30 \%$ and reduced $(P=0.04)$ fruit susceptibility to cracking and russeting by $68 \%$ (Table 1). Irrigation treatments had no significant effect on fruit size $(P=$ $0.14)$ or fruit cracking $(P=0.22)$. Increasing EC with $\mathrm{NaCl}$ and heavy watering (F1) decreased the incidence of fruit with gold speck from 6.4 to $5.1 \mathrm{~kg} \cdot \mathrm{m}^{-2}(P=0.02)$ (Table 1$)$. Irrigation regime had no effect on fruit deformity at high $\mathrm{EC}$, but the highest irrigation regime (F1) increased fruit deformity at the control EC, while the lowest irrigation regime $(\mathrm{F} 3)$ reduced it, resulting in significant interaction $(P=0.04)$. Salinity and irrigation regime had no significant effects on fruit susceptibility to BER $(P=0.43)$ or puffiness $(P=0.45)$ (Table 1$)$.

Increasing $\mathrm{EC}$ with $\mathrm{NaCl}$ significantly $(P=0.03)$ reduced the $\mathrm{N}$ concentration in the shoot, regardless of irrigation regime $(1.9 \% \mathrm{vs}$. $2.0 \%)$. The $\mathrm{Na}$ concentrations in shoots $(P=0.0001)$ and fruits $(P=0.0002)$ were increased $(0.61 \%$ vs. $0.16 \%$ and $0.15 \%$ vs. $0.04 \%$ in shoots and fruits, respectively). Phosphate levels in the slab nutrient solutions were reduced $(P=0.04)(0.43$ vs. $0.60 \mathrm{~mm}$ in high EC vs. control), whereas Na concentration was increased $(P=0.0004)(27.42$ vs. 3.66 $\mathrm{mm})$. The effects of $\mathrm{EC}$ and irrigation regime treatments on $\mathrm{K}, \mathrm{Ca}$, and $\mathrm{Mg}$ of shoot, fruit, and slab nutrient solution concentrations were nonsignificant when averaged over the duration of the experiment.

Plant water potential was not significantly affected by salinity $(P=0.37)$ or irrigation regime $(P=0.47)$ (data not shown). However, it was lower in June ( $-936 \mathrm{kPa}$ during the day, $-380 \mathrm{kPa}$ during the night) than in September (-644 $\mathrm{kPa}$ during the day, $-459 \mathrm{kPa}$ during the night). In June, the water potential of the nutrient solutions extracted from the rockwool slabs of the plants fertilized with the high EC was significantly lower $(P=0.02)$ than that from the control slabs $(-237 \mathrm{kPa}$ vs. $-182 \mathrm{kPa})$.

\section{Discussion}

For spring production (March to November), increasing salinity of the nutrient solution

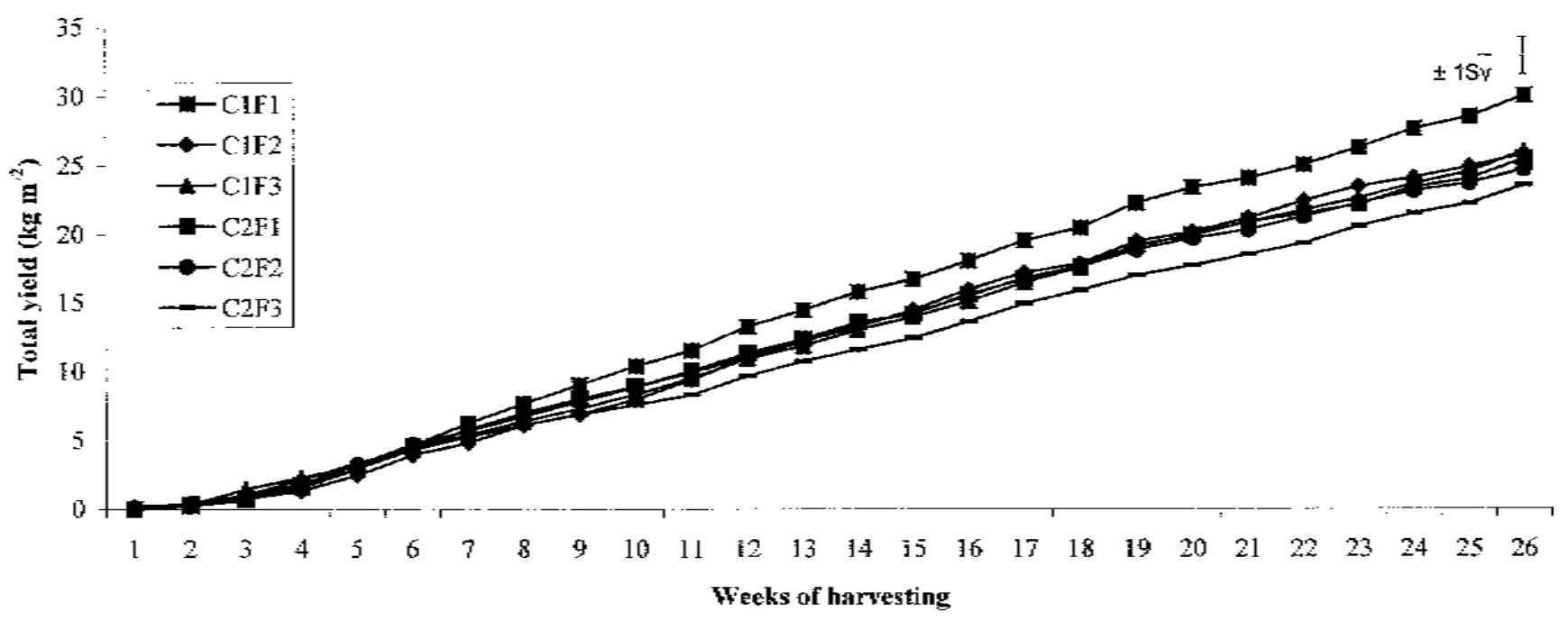

Fig. 2. Effects of electrical conductivity (EC) and irrigation treatments (F) on total yield of tomato $\left(\mathrm{kg} \cdot \mathrm{m}^{-2}\right)$ after 26 weeks of harvesting.

Table 1. Effects of electrical conductivity (EC) and irrigation (F) treatments on the total yield $\left(\mathrm{kg} \cdot \mathrm{m}^{-2}\right)$ of Class 1 (>90 ng), Class 2 (70-90 g) tomato fruits, and of fruits with physiological disorders during 26 weeks of harvesting.

\begin{tabular}{|c|c|c|c|c|c|c|c|}
\hline Treatments & Class 1 fruit & Yield of Class 2 fruit & Gold speck & Blossom-end rot & Deformity & Puffiness & Cracking $^{2}$ \\
\hline \multicolumn{8}{|c|}{ EC1 $\left(2.0\right.$ to $\left.3.5 \mathrm{mS} \cdot \mathrm{cm}^{-1}\right)$} \\
\hline $\mathrm{F} 1^{\mathrm{y}}$ & 6.9 & 0.175 & 6.4 & 1.5 & 2.2 & 8.7 & 1.3 \\
\hline $\mathrm{F} 2$ & 6.4 & 0.369 & 5.2 & 2.9 & 1.2 & 6.3 & 0.6 \\
\hline \multicolumn{8}{|c|}{ EC2 $\left(2.6 \text { to } 4.6 \mathrm{mS} \cdot \mathrm{cm}^{-1}\right)^{x}$} \\
\hline $\mathrm{F} 1$ & 8.0 & 0.328 & 5.1 & 2.2 & 1.0 & 6.6 & 0.3 \\
\hline $\mathrm{F} 2$ & 7.2 & 0.496 & 5.0 & 1.7 & 1.2 & 6.2 & 0.3 \\
\hline $\mathrm{F}$ & 0.603 & 0.145 & 0.290 & 0.847 & 0.844 & 0.164 & 0.218 \\
\hline EC & 0.807 & 0.013 & 0.209 & 0.919 & 0.087 & 0.104 & 0.038 \\
\hline $\mathrm{F} \times \mathrm{EC}$ & 0.303 & 0.256 & 0.025 & 0.435 & 0.042 & 0.453 & 0.376 \\
\hline \multicolumn{8}{|c|}{ Contrasts } \\
\hline F linear × (EC1 vs. EC2) & 0.155 & 0.129 & 0.009 & 0.831 & 0.035 & 0.849 & 0.261 \\
\hline F quadratic $\times(\mathrm{EC} 1$ vs. $\mathrm{EC} 2)$ & 0.587 & 0.574 & 0.806 & 0.220 & 0.096 & 0.231 & 0.412 \\
\hline
\end{tabular}

${ }^{\mathrm{R}}$ Russeting, radial and concentric cracking.

'Irrigation: $\mathrm{F} 1=468, \mathrm{~F} 2=540, \mathrm{~F} 3=612 \mathrm{KJ} \cdot \mathrm{m}^{-2}$.

${ }^{x} \mathrm{EC} 2$ adjusted using $12 \mathrm{mmol} \cdot \mathrm{L}^{-1} \mathrm{NaCl}$. 
(1.8-3.5 to $\left.2.3-4.6 \mathrm{mS} \cdot \mathrm{cm}^{-1}\right)$ did not reduce growth. However, from May to July, increasing EC under the control irrigation regime treatment (F2) increased SLA. Al-Rawahy et al. (1990) reported that dry matter production and $\mathrm{N}$ uptake of tomato plants were significantly lower when the salinity was raised from 30 to $400 \mathrm{kPa}$ with $24 \mathrm{~mm} \mathrm{NaCl}$. They suggested that these responses might result from a combination of osmotic and specific ion effects of $\mathrm{Cl}^{-}$and/or $\mathrm{Na}^{+}$. In agreement with this study, we observed that increasing salinity up to $4.6 \mathrm{mS} \cdot \mathrm{cm}^{-1}$ during spring production reduced $\mathrm{N}$ uptake, expressed as shoot $\mathrm{N}$ concentration. This may be explained by an antagonistic effect of $\mathrm{Cl}^{-}$on $\mathrm{NO}_{3}^{-}$uptake. Nitrate reductase (NR) activity of tomato leaves was reduced by high $\mathrm{NaCl}$ concentration $(60$ $\mathrm{mM}$ ) in the nutrient solution (Martinez and Cerda, 1989); this in turn reduced $\mathrm{N}$ uptake and foliar $\mathrm{N}$ content.

The balance between vegetative and reproductive growth, expressed by the harvest index, was not affected by increasing the EC. However, increasing the salinity increased the weight of Class 2 (smaller) fruits. Adams and Ho (1989) reported that salinity affects fruit size by reducing water content rather than dry matter accumulation. However, total yield and Class 1 (larger) fruits in our experiment were not affected by the treatments, whereas the total weight of fruits with cracking, especially with russeting, was reduced by increasing the EC. Fruit cracking is generally associated with the rapid net influx of water and solutes into the fruit when cuticle elasticity and strength are reduced (Peet, 1992). Salinity has a profound effect on the water relations of plants because osmotic stress reduces uptake of water (Ho and Adams, 1995). Even though raising EC did not significantly affect fruit dry matter in our study, the resulting reduction in water uptake may explain the reduction of fruit size and cracking.

High EC can reduce Ca uptake, even though the $\mathrm{Ca}$ concentration is high in the nutrient solution, and induce a local Ca deficiency in tomato fruit called blossom-end rot (BER) (Ho and Adams, 1995). In our experiment, increasing $\mathrm{EC}$ with $\mathrm{NaCl}$ did not increase the incidence of fruits with BER or decrease fruit $\mathrm{Ca}$ concentration. This might be explained by a higher $\mathrm{Ca}$ uptake resulting from a higher chloride concentration in the nutrient solution. According to Nukaya (1992), a chloride concentration of $8-13 \mathrm{mmol} \cdot \mathrm{L}^{-1}$ increases $\mathrm{Ca}$ uptake, reduces the incidence of BER, and may increase the number of fruits with gold specks. In our study, increasing $\mathrm{EC}$ with $\mathrm{NaCl}$ [up to $12 \mathrm{mmol} \cdot \mathrm{L}^{-1}$ under the highest irrigation regime treatment $(\mathrm{F} 1)]$ reduced the incidence of fruit with gold specks by $20 \%$, but had no effect on fruit $\mathrm{Ca}$ concentration.

High $\mathrm{K}$ in the nutrient solution is essential for good tomato quality (color, firmness, shelflife, and taste), and influences the content of titratable acids. Moreover, Davies and Winsor (1967) noted a positive effect of K on fruit sugar content, dry matter accumulation and gustatory quality. As K concentrations in the nutrient solution increased from 180 to 280 to
$380 \mathrm{mg} \cdot \mathrm{L}^{-1}$, Gormley and Maher (1990) noted a reduction in the number of fruits with uneven coloration from $40 \%$ to $21 \%$ to $12 \%$, respectively. Potassium is also essential for many plant processes, including protein synthesis, enzyme activation, membrane transport, charge balancing, and the generation of turgor. For this reason, the application of $\mathrm{NaCl}$ to partially replace major nutrients and/or increase nutrient solution salinity should be done with care, as the uptake of $\mathrm{K}$ may be reduced by $\mathrm{Na}$ in the solution, thus reducing $\mathrm{K}$ content of the fruit (Adams, 1991; Adams and Ho, 1989). In our study, $12 \mathrm{mmol} \cdot \mathrm{L}^{-1}$ of $\mathrm{NaCl}$ in the nutrient solution did not significantly reduce shoot and fruit $\mathrm{K}$ concentration. No significant difference in fruit coloration during ripening was observed between high EC $\left(12 \mathrm{mmol} \cdot \mathrm{L}^{-1} \mathrm{NaCl}\right)$ and control $\mathrm{EC}$ (without $\mathrm{NaCl}$ ) treatments (data not shown). Partial replacement of major nutrients such as nitrate by $\mathrm{NaCl}, \mathrm{KCl}$, or $\mathrm{CaCl}_{2}$ is an excellent tool to improve fruit quality and reduce environmental pollution.

A desirable balance between vegetative and reproductive growth can be achieved by water management (Cooper, 1978). In addition, well-controlled irrigation may improve fruit quality in terms of cracking, size, and flavor (Abbott et al., 1986; Ho and Adams, 1995; Peet, 1992). In our study, regardless of EC levels, irrigation treatments did not affect growth, water potential, tissue mineral content, or fruit quality. Moreover, vegetative and reproductive vigor of the plants, as expressed by the harvest index, was not modified. In contrast with the results obtained by Peet and Willits (1995), the percentage of cracked fruit did not increase when a higher daily volume of nutrient solution was applied per plant, possibly because of differences in media (peat bags vs. rockwool) and experimental conditions. Under Northern European growing conditions, Ho and Adams (1995) reported that the volume and frequency of irrigation for a fruiting tomato crop is $120-130 \mathrm{~mL} \cdot \mathrm{MJ} \cdot \mathrm{m}^{-2}$ of solar radiation received per plant. Under climatic conditions prevailing in Quebec for spring production, $214 \mathrm{~mL} \cdot \mathrm{MJ} \cdot \mathrm{m}^{-2}$ per plant was required for good marketable yield. Therefore, volume and frequency of fertigation may vary significantly according to the irradiance, i.e., in climates with higher irradiance, a higher irrigation rate per MJ may be required.

Control of EC and water management allows the grower to modify the water availability to the crop and influences fruit quality (Holder and Christensen, 1989; Pearce et al., 1993; Rudich et al., 1977). Water stress or high EC, however, may affect uptake of nutrients such as Ca (Ehret and Ho, 1986), as well as fruit growth rate (Pearce et al., 1993) and quality (BER, small fruit size). Our results demonstrate that lower EC, combined with higher irrigation in the period of high solar radiation (July, August), increase water and mineral assimilation, resulting in a better yield (Fig. 2). These results agree with earlier observations (Tüzel et al., 1994) and suggest that increasing irrigation during the summer increases yield. However, under the high irrigation regime, the incidence of misshapen and gold speck fruit was greater at low EC. The presence of gold speckle deposits near the calyx affects the external appearance and reduces shelf-life of fruit. This phenomenon was related to high uptake of $\mathrm{Ca}$ (de Kreij et al., 1992). High levels of $\mathrm{P}$ or $\mathrm{Cl}$ also favor gold specks due to their positive effect on $\mathrm{Ca}$ uptake.

Our results suggest that increasing EC (2.6 to $4.6 \mathrm{mS} \cdot \mathrm{cm}^{-1}$ ) with $\mathrm{NaCl}$ (up to 12 $\mathrm{mmol} \cdot \mathrm{L}^{-1}$ ) improves tomato fruit quality without affecting total yield and plant development. The use of $\mathrm{NaCl}$ both reduced the cost of fertilizer and environmental pollution from nitrate and other plant nutrients. However, increasing the water supply as global solar radiation increased improved tomato yield in the last few months of production but reduced fruit quality (more gold specks, misshapen fruits). Research is needed on the interaction between EC and water management at different crop stages and light levels on nutrient uptake, water stress, and fruit size and quality.

\section{Literature Cited}

Abbott, J.D., M.M. Peet, D.H. Willits, D.C. Sanders, and R.E. Gough. 1986. Effects of irrigation frequency and scheduling on fruit production and radial fruit cracking in greenhouse tomatoes in soil beds and in a soilless medium in bags. Scientia. Hort. 28:209-217.

Adams, P. 1987. The test of raised salinity. The Grower 107:23-27.

Adams, P. 1989. Some effects of root temperature on the growth and nutrient uptake of tomatoes in NFT, p. 73-82. In: Soc. for Soilless Culture Intl. Proc. 7th Intl. Congr. on Soilless Culture. Wageningen, The Netherlands.

Adams, P. 1991. Effects of increasing the salinity of the nutrient solution with major nutrients or sodium chloride on the yield, quality and composition of tomatoes grown in rockwool. J. Hort. Sci. 66:201-208.

Adams, P. and L.C. Ho. 1989. Effects of constant and fluctuating salinity on the yield, quality and calcium status of tomatoes. J. Hort. Sci. 64:725732.

Al-Rawahy, S.A., J.L. Stroehlein, and M. Pessarakli. 1990. Dry-matter yield and nitrogen- $15, \mathrm{Na}, \mathrm{Cl}$, and $\mathrm{K}$ content of tomatoes under sodium chloride stress. J. Plant Nutr. 15:341-358.

Atherton, J.G. and J. Rudich. 1986. The tomato crop: A scientific basis for improvement. Chapman and Hall, New York. p. 581-644.

Bremner, J.M. and C.S. Mulvaney. 1982. Nitrogentotal, p. 595-624. In: A.L. Page, R.H. Miller, and D.R. Keeney (eds.). Methods of soil analysis. Part 2; Chemical and microbiological properties, 2nd ed. Amer. Soc. Agron., Soil Sci. Soc. Amer., Madison, Wis.

Brown, R.H. 1984. Growth of the green plant, p. 153-174. In: M.B. Tesar (ed.). Physiological basis of crop growth and development. Amer. Soc. Agron., Crop Sci. Soc. Amer., Madison, Wis.

Chapman, H.D. and P.F. Pratt. 1961. Methods of analysis for soils, plants and waters. Div. of Agr. Sci., Univ. California, Davis.

Cooper, A.J. 1978. Methods of establishing young plants in a nutrient-film crop. J. Hort. Sci. 53:189193.

Davies, J.N. and G.W. Winsor. 1967. Effect of 
nitrogen, phosphorus, potassium, magnesium and liming on the composition of tomato fruit. J. Sci. Food Agr. 18:459-466.

de Halleux, D. and L. Gauthier. 1998. Energy consumption due to dehumidification of greenhouses under northern latitudes. J. Agr. Eng. Res. 69:35-42.

de Kreij, C. 1995. Latest insights into water and nutrient control in soilless cultivation. Acta Hort 408:47-61.

de Kreij, C., J. Janse, B.J. van Goor, and J.D.J. van Doesburg. 1992. The incidence of calcium oxalate crystals in fruit walls of tomato (Lycopersicon esculentum Mill.) as affected by humidity, phosphate and calcium supply. J. Hort. Sci. 67:45-50.

Ehret, D.L. and L.C. Ho. 1986. Translocation of calcium in relation to tomato fruit growth. Ann. Bot. 58:679-688.

Gormley, T.R. and M.J. Maher. 1990. Tomato fruit quality-An interdisciplinary approach. Prof. Hort. 4:107-112.

Ho, L.C. and P. Adams. 1995. Nutrient uptake and distribution in relation to crop quality. Acta Hort. 396:33-44.

Holder, R. and M.H. Christensen. 1989. The effects of electrical conductivity on the growth, yield and composition of cherry tomatoes grown on rockwool, p. 213-228. In: Soc. for Soilless
Culture Intl. Proc. 7th Intl. Congr. on Soilless Culture. Wageningen, The Netherlands.

Isaac, R.A. and N.W.C. Johnson. 1960. Determination of total nitrogen of plant tissue using BD-40 digestion. J. AOAC 59:98-100.

Martinez, V. and A. Cerda. 1989. Nitrate reductase activity in tomato and cucumber leaves as influenced by $\mathrm{NaCl}$ and $\mathrm{N}$ source. J. Plant Nutr. 12:1335-1350.

Massey, D.M., A.C. Hayward, and G.W. Winsor. 1984. Some responses of tomatoes to salinity in nutrient film culture, p. 60-62. In: Annu. Rpt. Glasshouse Crops Res. Inst. Warwick, U.K.

Murphy, J. and H.P. Riley. 1962. A modified single solution method for the determination of phosphate in natural waters. Anal. Chim. Acta 27:31-36.

Norman, R.J., J.C. Edberg, and J.W. Stucki. 1985. Determination of nitrate in soil extracts by dualwavelength ultraviolet spectrophotometry. Soil Sci. Soc. Amer. J. 49:1182-1185.

Nukaya, A. 1992. Effects of $\mathrm{NO}_{3}, \mathrm{SO}_{4}$ and $\mathrm{Cl}$ ratios on tomatoes grown in recirculating system. Acta Hort. 303:91-98.

Pearce, B.D., R.I. Grange, and K. Hardwick. 1993. The growth of young tomato fruit. II. Environmental influences on glasshouse crops grown in rockwool or nutrient film. J. Hort. Sci. 1:1323.
Peet, M.M. 1992. Fruit cracking in tomato. HortTechnology 2:216-223.

Peet, M.M. and D.H. Willits. 1995. Role of excess water in tomato fruit cracking. HortScience 30:65-68.

Rudich, J., D. Kalmar, C. Geizenberg, and S. Harvel. 1977. Low water tension in defined growth stages of processing tomatoes and their effects on yield and quality. J. Hort. Sci. 52:391-400.

Sonneveld, C. and A.M.M. Van Der Burg. 1991. Sodium chloride salinity in fruit vegetable crops in soilless culture. Neth. J. Agr. Sci. 39:115122.

Steel, R.G.D. and J.H. Torrie. 1980. Principles and procedures of statistics. A biometrical approach. $2^{\text {nd }}$ ed. McGraw-Hill, New York.

Tüzel, Y., M.A. U1, and I.H. Tüzel. 1994. Effects of different irrigation intervals and rates on spring season glasshouse tomato production: II. Fruit quality. Acta Hort. 366:389-396.

Voogt, W. and C. Sonneveld. 1997. Nutrient management in closed growing systems for greenhouse production, p. 83-102. In: E., Goto (ed.). Plant production in closed ecosystems. Kluwer Academic, Boston.

Xu, H.L., L. Gauthier, and A. Gosselin. 1997. Greenhouse tomato photosynthetic acclimation to water deficit and response to salt accumulation in the substrate. J. Jpn. Soc. Hort. Sci. 65:777-784. 